\title{
Considerations on the effects of tidal regimes in the movement of floating litter in an estuarine environment: Case study of the estuarine system of Santos-São Vicente, Brazil
}

Gerson Fernandino ${ }^{\mathrm{a},{ }^{*}}$, Carla Isobel Elliff a, Gabriela Amado Frutuoso ${ }^{\mathrm{b}}$, Eric Vinícius Nascimento Malaquias da Silva ${ }^{b}$, Guilherme Santiago Gama ${ }^{b}$, João Henrique de Oliveira Sousa ${ }^{b}$, Iracema Reimão Silva ${ }^{a}$

a Postgraduate Program in Geology, Núcleo de Estudos Hidrogeológicos e do Meio Ambiente NEHMA, Instituto de Geociências, Universidade Federal da Bahia, Salvador, Brazil

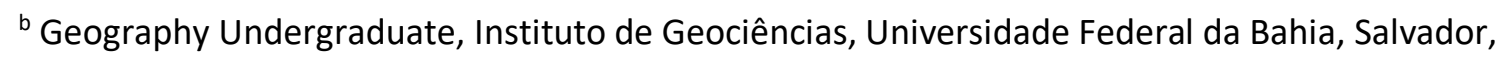
Brazil

\section{Abstract}

Floating litter in the estuarine system of Santos-São Vicente is common and is part of day-to-day activities of various users of the area. The objective of the present study was to carry out a qualiquantitative evaluation of the occurrence of floating litter, to infer their sources, and to identify environmental factors that are likely to control occurrence and distribution, with particular emphasis on the effects of tidal regimes. Six sampling stations were selected along the aforementioned estuary and visited monthly between July 2010 and January 2012. Floating litter was counted from a fixed sampling station. Plastics prevailed (89.64\%) and their main source was domestic activities (55.41\%). More litter was found during ebb spring tides, with higher concentrations obeying confluence patterns of the estuary's channels. Results indicated that occurrence can be attributed to the deficiency in basic sewage system in the area and the deliberate disposal into the estuary by the local population.

Marine litter is currently considered one of the major environmental problems related to the marine environment. According to Cheshire et al. (2009), over $80 \%$ of all litter found in the marine environment consists of plastics and approximately $85 \%$ is from land-based sources.

Although present in virtually all beaches and marine environments in the world, litter is observed in higher concentrations in coastal environments adjacent to urban centers (Moore and Allen, 2000), either stranded on beaches, deposited on the seafloor or suspended in the water column. When 
found either floating on the water surface or suspended in the water column, litter is designated as "floating litter" (USEPA, 2002).

Floating litter poses clear threats to pelagic habitats. Among these are: i) increased mortality of organisms by ingesting plastic and/or reduced mobility of species through entanglement or ghostfishing; ii) transportation of organisms that use floating material as a means for dispersion, including alien species; iii) reduced quality in available food due to the presence of toxins ingested along with plastic particles; and iv) alteration of the behavior of species that use litter as fish aggregation devices (e.g. Barnes, 2002, Hallier and Gaertner, 2008, Van Franeker, et al. 2011 and Majer et al., 2012). This can bring important consequences for local populations who have fisheries as a major source of income. In addition, floating litter can bring economic losses to small vessels and compromise local tourism activities due to the loss of aesthetic potential of the environment (Spengler and Costa, 2008).

Various environmental factors control the distribution of marine litter. Hydrodynamic circulation is particularly relevant to marine litter distribution (e.g. Galgani et al., 1995 and Corcoran et al., 2009). Winds, and tidal regimes, combined with rivers and channels that flow into marine environments, as well as salinity gradient and local circulation patterns can play an important role in the control of litter dispersion and distribution (Parreira, 2012).

The general objective of the present study was to assess, for the first time in Brazil, the occurrence and sources of floating litter in the estuarine system of Santos-São Vicente, in the coast of the state of São Paulo. Source identification is paramount for mitigating the problem.

The estuarine system of Santos-São Vicente, central coast of the state of São Paulo, is located between the Atlantic Ocean (southwards) and the scarps of the Serra do Mar. (northwards). The area presents both high ecological and economic relevance due to the presence of wide mangrove forests, notable variety of animal species, and the presence of the Port of Santos, respectively (Fig. 1). The municipality of Santos is part of the Baixada Santista Metropolitan Area (BSMA), the third largest metropolitan area of the state of São Paulo, and presents over 400,00 inhabitants (IBGE, Instituto Brasileiro de Geografia e Estatística, 2010). Moreover, Santos presents humid tropical climate, with mean temperatures of $20^{\circ} \mathrm{C}$ and mean rainfall between 2000 and $2500 \mathrm{~mm} /$ year (Parreira, 2012). Summers are warm and humid, and winters present cooler temperatures and lower rainfall, but without the presence of a dry season, with mean rainfall higher than $60 \mathrm{~mm}$ during the driest months (SSE, Secretaria de Saneamento e Energia do Estado de São Paulo, 2010).

The municipality of Santos is considered one of the greatest development poles in Brazil, presenting various large-scale economic activities such as industries, fishery, people and goods maritime transportation, and tourism/recreational activities (Harari and Camargo, 1998).

The hydrodynamic circulation of the estuarine system of Santos-São Vicente is essentially governed by semidiurnal tides (microtidal regime), with occurrence of mixed tides, with daily inequalities and the periodic approach of cold fronts that contribute to the momentary variation of local mean sea level (Harari and Camargo, 1995). Tidal wave propagation is conditioned to the existence of different 
axes of flood and ebb tides, to the presence of wide areas covered with mangrove forests (which are areas with particular circulation patterns), and to the encounter between the Estuary of São Vicente (westwards) and the Estuary of Santos (eastwards), in the vicinities of the Casqueiro River (Parreira, 2012). Wind shearing on the water surface also plays an important role in circulation, especially combined with surface circulation which is controlled by the fresh water that flows into the area (usually towards the ocean) and by the bottom currents generated by the incursion of saline waters (Harari et al., 2007).

Punctual and dispersed pollution sources are industrial and urban effluents (Harari and Camargo, 1998), including solid waste -- approximately 3000 tons of litter per year (SSE, Secretaria de Saneamento e Energia do Estado de São Paulo, 2010) --, fisheries, and tourism and recreational activities. In the estuarine system of Santos-São Vicente there are also garbage dumps and landfills (both active and inactive) that can contribute as pollution sources for the local environment. In addition, irregular dwellings/stilt houses are found in various areas along the channels of Santos and São Vicente, more specifically in their innermost areas, including the industrial complex of Cubatão (see Fig. 1).

Floating litter data sampling was performed through visual censuses. A total of six sampling stations were chosen for the monitoring (see Fig. 1). Stations were visited monthly, in a total of 17 sampling campaigns (between July 2010 and January 2012). In each campaign, data was gathered in two periods (morning and afternoon) in each station, representing different tide conditions (ebb and flood) in the majority of cases.

Observations were performed from a fixed sampling station (anchored vessel), for $30 \mathrm{~min}$, with two observers registering all floating litter visible to the naked eye within a radius of approximately $50 \mathrm{~m}$. Information on tide regime and weather conditions were concomitantly collected.

All floating litter items observed were classified according to material: plastic, metal, cloth, rubber, glass/ceramic, paper/cardboard, and others (Cheshire et al., 2009; Zhou et al., 2011; Fernandino et al., 2015). Their most probable origins (sources) were inferred according to surrounding characteristics and distributed into the following source categories: domestic, tourism/recreation, fisheries, hospital, and indeterminate (Fernandino et al., in press).

A total of 2339 items of floating litter was registered. The campaigns with higher occurrence of litter were C4 and C8, with 299 items observed in each, representing together $24.90 \%$ of all observed material during the sampling period. On the other hand, the campaign with the lowest occurrence of litter was C3, with 31 items (1.29\%). The stations that concentrated the highest counting, considering the entire sampling period, were station 1, with 690 items of floating litter, and station 2, with 615. The lowest concentration was observed in station 5, with 137 items (Fig. 2).

Two major specific sources were identified: "domestic" (55.41\%) and "indeterminate" (42.71\%) (Fig. 2). The latter category ("indeterminate") refers to items that did not allow for the identification of sources, for instance plastic fragments, or items that could present multiple sources according to local characteristics. The remaining sources identified were "tourism/recreation" (1.36\%), "fishery" 
$(0.43 \%)$ and "hospital" (0.09\%). As expected, all floating litter found in the estuarine system of Santos-São Vicente originated from land-based and urban activities. This predominance was also observed by other authors in other estuaries and beaches in Brazil (Araújo and Costa, 2007; Ivar Do Sul and Costa, 2013).

The fact that the category "domestic" presented the highest representativeness can be related to the strong presence of irregular dwellings/stilt houses in a large portion of the estuarine system where litter and domestic effluents are dumped directly into the water (Figs. 1 and 3).

The hydrodynamic circulation in the area strongly influences the dispersion of chemical pollutants in the estuarine system of Santos-São Vicente (Parreira, 2012). Moreover, this author also observed that the energy of this circulation is higher in the Port of Santos Channel, facilitating dispersion. Such a pattern could also occur with floating litter. The study conducted by Harari and Camargo (1998) showed that under ebb spring tide conditions, velocity vectors indicated water flow from the São Vicente Channel towards the Port of Santos Channel, moving towards the Bay of Santos. This information corroborates the hypothesis of contribution of the stilt houses to local litter. In addition, for these same conditions, water movement was also observed from the Bertioga Channel towards the Port of Santos Channel, thus indicating a possible contribution of the Bertioga Channel in the input of litter to the area, especially considering the existence of riverine communities along its margins. These data were integrated in Fig. 3 to illustrate the distribution of floating litter in the estuarine complex of Santos-São Vicente.

Higher concentrations of litter were found in stations 1 and 2, which could be the result of the confluence of the flow from both channels. Floating items from the innermost areas of the estuarine system can join those from the Bertioga Channel in the vicinities of station 2.

As expected, a high predominance of plastics was observed (89.64\%) (Fig. 2). This finding corroborates with the study conducted by Sadri and Thompson (2014). Cloth (0.17\%), glass (0.30\%), metal $(0.64 \%)$, paper $(0.47 \%)$, rubber $(2.13 \%)$, wood $(4.22 \%)$ and others $(2.43 \%)$ occurred in lower amounts probably as a result of the higher densities that are typical of these materials, which allow them to sink to the bottom more easily than plastic items.

The highest daily tide amplitudes during the sampling campaigns were $1.5 \mathrm{~m}$ (C8 and C11), and the lowest was $0.4 \mathrm{~m}$ (C1). In absolute numbers, a higher quantity of litter was found during spring tides (1227 items) when compared to neap tides (1097). A similar pattern was found by Sadri and Thompson (2014), in a macrotidal estuary in the UK, who found a higher abundance of litter during spring tides.

The small discrepancy found in the present study between the values found during spring and neap tides may be attributed to the fact that the studied estuary presents a microtidal regime, varying between semidiurnal and mixed tides, often presenting variations lower than $0.5 \mathrm{~m}$ during neap tides. Thus, during small neap tide amplitudes, the ebb tidal current may not be competent enough to transport part of the litter towards the Bay of Santos, adjacent to the estuary. Therefore, part of the litter would be contained within the estuary "awaiting" higher tidal amplitude that would be 
capable to transport it outside the estuarine system.

Spring tides occurred in nine campaigns ( $\mathrm{C} 5, \mathrm{C} 8, \mathrm{C} 9, \mathrm{C} 11, \mathrm{C} 12, \mathrm{C} 13, \mathrm{C} 14, \mathrm{C} 15$ and $\mathrm{C} 16)$, while neap tide were identified for six campaigns $(\mathrm{C} 1, \mathrm{C} 2, \mathrm{C} 3, \mathrm{C} 4, \mathrm{C} 6$ and $\mathrm{C} 10)$. Campaigns with "variable" tides (one day considered as spring tide and another, neap tide) occurred in two occasions (C7 and C17). Due to the difference between the number of campaigns sampled in each tidal regime, higher mean values were found for neap tides ( $n=6$ campaigns; 173.33 items/campaigns), and lower mean values for spring tides ( $n=9$ campaigns; 121.56 items/campaign), excluding the data from the campaigns with "variable" tide.

In general, more items of floating litter were found during ebb tides (1425 items) when compared to the number found during flood tides (914 items). The higher quantity found during ebb tides can be attributed to the behavior of the tide itself that, when ebbing, carries the material that is in the inner areas of the estuary and transport it towards the Bay of Santos. Table 1 describes the occurrence of litter according to tide regimes.

The climatic/rainfall regime of the area may have influenced the higher quantity of litter found during summer (746 items) and spring (735 items). Higher rainfall during these seasons may allow higher flow of litter from the streets directly into the estuary through surface drainage system, increasing the frequency of items found. Although winter in the area is considered of lower rainfall, the high incidence of cold fronts in the area could have influenced the high value of floating litter observed during this period (538 items).

Morritt et al. (2014) showed that considerable quantities of litter are transported close to the riverbed. This can be due to natural mixing and stratification processes that are characteristic of estuaries. Thus, it is reasonable to infer that this phenomenon can occur in the studied estuary. In addition, the low hydrodynamic characteristic of the estuarine complex of Santos-São Vicente (Parreira, 2012) allows litter items to have enough time to deposit on the floor. Therefore, analyzing only the floating material is an underestimation of the real state of pollution by solid waste in this environment.

The main source of floating litter in the area was domestic activities, likely from irregular dwellings/stilt houses located in areas near the port. The litter found was mainly comprised of plastics. The confluence of waters from the innermost areas of the estuarine system of Santos-São Vicente and the Bertioga Channel in the vicinities of station 2 helps to explain the higher concentrations of litter found in this portion of the studied estuary. In addition, more items were found during ebb tides, reflecting the role of tides in the transportation of litter in the innermost areas of the estuary towards the Bay of Santos through the Porto de Santos Channel.

Some strategic actions should make a great difference in reducing the inadequate disposal of litter by irregular dwellings/stilt houses, such as projects for improving and implementing new sanitary sewage systems in these areas.

The concentration of floating litter in the area poses serious threats to the local fauna, considering 
that various marine animals can ingest or become entangled in floating litter, such as fish and turtles, commonly found in the area. Scenic beauty can also be compromised by the quantity of litter found floating at the surface. Although the studied area is not necessarily sought by tourists throughout the year who intensively use beaches close to the sampling stations. The litter found in the estuary can be carried by tides and eventually be deposited on these beaches, reducing scenic attractiveness and posing risks to users who can eventually get hurt by the stranded material.

In addition to the problem involving basic sewage system, public awareness is necessary because even after solving the sewage problem, the direct disposal of litter would still occur in the estuarine area. Therefore, campaigns aiming the promotion of environmental education of populations of the area should be conducted in order to reduce the input of litter in this estuarine system.

\section{Acknowledgements}

G. Fernandino thanks the National Counsel of Technological and Scientific Development (CNPq) for his PhD scholarship; C.I. Elliff thanks the Coordination for the Improvement of Higher Education Personnel (CAPES) for her PhD scholarship; I.R. Silva also thanks CNPq for her research productivity grant. All authors thank the staff of the company PROBIOTA Consultoria Ambiental, especially consultants Bárbara de Loreto and Natália Bahia for their help and companionship during sampling, and the various boat pilots who allowed for the safe execution of the onboard observations and helped maintaining good mood even during rainy days.

\section{References}

Araújo, M.C., Costa, M., 2007. An analysis of the riverine contribution to the solid waste contamination of an isolated beach at the Brazilian northeast. Manag. Environ. Qual. 18 (1), 6-12.

Barnes, D.K.A., 2002. Invasions by marine life on plastic debris. Nature $412,808-809$.

Cheshire, A., Adler, E., Barbiere, J., Cohen, Y., Evans, S., Jarayabhand, S., Jeftic, L., Jung, R., Kinsey, S., Kusui, T., Lavine, I., Manyara, P., Ooesterbaan, L., Pereira, M., Sheavly, S., Tkalin, A., Varadarajan, S., Wenneker, B., Wesrphalen, G., 2009. UNEP/IOC Guidelines on Survey and Monitoring of Marine Litter. UNEP Regional Seas Reports and Studies. (Accessed 22 March 2016) http://www.unep.org/regionalseas/marinelitter/publications/docs/Marine_Litter_Survey_and_Moni toring_Guidelines.pdf.

Corcoran, P.L., Biesinger, M.C., Grifi, M., 2009. Plastics and beaches: a degrading relationship. Mar. Pollut. Bull. 58 (1), 80-84.

Fernandino, G., Elliff, C.I., Silva, I.R., 2015. Degree of pollution by benthic litter in beaches in Salvador, Bahia, Brazil. Scientia Plena 11 (3), 1-9.

Fernandino, G., Elliff, C.I., Silva, I.R., Brito, T.S., Bittencourt, A.C.S.P. Plastic fragments as a major component of marine litter: a case study in Salvador, Bahia, Brazil. Journal of Integrated Coastal Zone Management, 16:7p (in press). 
Galgani, F., Burgeot, T., Bocquene, G., Vincent, F., Leaute, J.P., Labastie, J., Forest, A., Guichet, R., 1995. Distribution and abundance of debris on the continental shelf of the Bay of Biscay and in Seine Bay. Mar. Pollut. Bull. 30 (1), 58-62.

Hallier, J.P., Gaertner, D., 2008. Drifting fish aggregation devices could act as an ecological trap for tropical tuna species. Mar. Ecol. Prog. Ser. 353, 255-264.

Harari, J., Camargo, R., 1995. Tides and mean sea level variabilities in Santos (SP), 1944 to 1989. Relatório Interno, Instituto Oceanográfico USP. 36, pp. 1-15.

Harari, J., Camargo, R., 1998. Modelagem numérica da região costeira de Santos (SP): Circulação de maré. Rev. Bras. Oceanogr. 46 (2), 135-156.

Harari, J., França, C.A.S., Marques, J., 2007. Aplicações da modelagem numérica da Baía de Santos (SP, Brasil): correntes residuais e dispersão de poluentes. I Encontro Internacional: Governança da Água na América Latina, pp. 1-15.

IBGE (Instituto Brasileiro de Geografia e Estatística), 2010. Censo Demográfico - Santos. http://cidades.ibge.gov.br/xtras/perfil.php?codmun=354850 (Accessed 23 February 2016).

Ivar Do Sul, J.A., Costa, M.F., 2013. Plastic pollution risks in an estuarine conservation unit. J. Coast. Res. 1, 48-53 Special Issue No. 65 International Coastal Symposium.

Majer, A.P., Vedolin, M.C., Turra, A., 2012. Plastic pellets as oviposition site and means of dispersal for the ocean-skater insect Halobates. Mar. Pollut. Bull. 64 (6), 1143-1147.

Moore, S.L., Allen, M.J., 2000. Distribution of anthropogenic and natural debris on the mainland shelf of the Southern California Bight. Mar. Pollut. Bull. 40 (1), 83-88.

Morritt, D., Stefanoudis, P.V., Pearce, D., Crimmen, O.A., Clark, P.F., 2014. Plastic in the Thames: a river runs through it. Mar. Pollut. Bull. 78 (1-2), 196-200.

Parreira, C.N., 2012. Avaliação da hidrodinâmica e da poluição no Canal de Piaçaguera, no estuário de Santos-São Vicente (SP), a partir de informações ambientais e modelagem numérica. Master in Science degree dissertation. Programa de Pós-Graduação em Ciência Ambiental (PROCAM). Universidade de São Paulo, São Paulo http://www.teses.usp.br/teses/disponiveis/90/90131/tde04072012-140310/pt-br.php. Access 22 March 2016176 p.

Sadri, S.S., Thompson, R.C., 2014. On the quantity and composition of floating plastic debris entering and leaving the Tamar Estuary, Southwest England. Mar. Pollut. Bull. 81 (1), 55-60.

Spengler, A., Costa, M.F., 2008. Methods applied in studies of benthic marine debris. Mar. Pollut. Bull. 56 (2), 226-230.

SSE (Secretaria de Saneamento e Energia do Estado de São Paulo), 2010a. Plano Regional Integrado de Saneamento Básico para a UGRHI 7 - Baixada Santista, Governo do Estado de São 
Paulo.http://www.saneamento.sp.gov.br/PMS/UGRHI07/PRS_UGRHI07.pdf (Accessed 22 March 2016).

USEPA, 2002. Assessing and Monitoring Floatable Debris. Environmental Protection Agency, Washington http://www.swrcb.ca.gov/water_issues/programs/swamp/docs/cwt/guidance/4315.pdf (Accessed 26 July 2010).

Van Franeker, J.A., Blaize, C., Danielsen, J., Fairclough, K., Gollan, J., Guse, N., Hansen, P.L., Heubeck, M., Jensen, J.K., Le Guillou, G., Olsen, B., Olsen, K.O., Pedersen, J., Stienen, E.W.M., Turner, D.M., 2011. Monitoring plastic ingestion by the northern fulmar Fulmarus glacialis in the North Sea.

Environ. Pollut. 159 (10), 2609-2615.

Zhou, P., Huang, C., Fang, H., Cai, W., Li, D., Li, X., Yu., H., 2011. The abundance, composition and sources of marine debris in coastal seawaters or beaches around the northern South China Sea (China). Mar. Pollut. Bull., 62:1998-2007

\section{Figures}
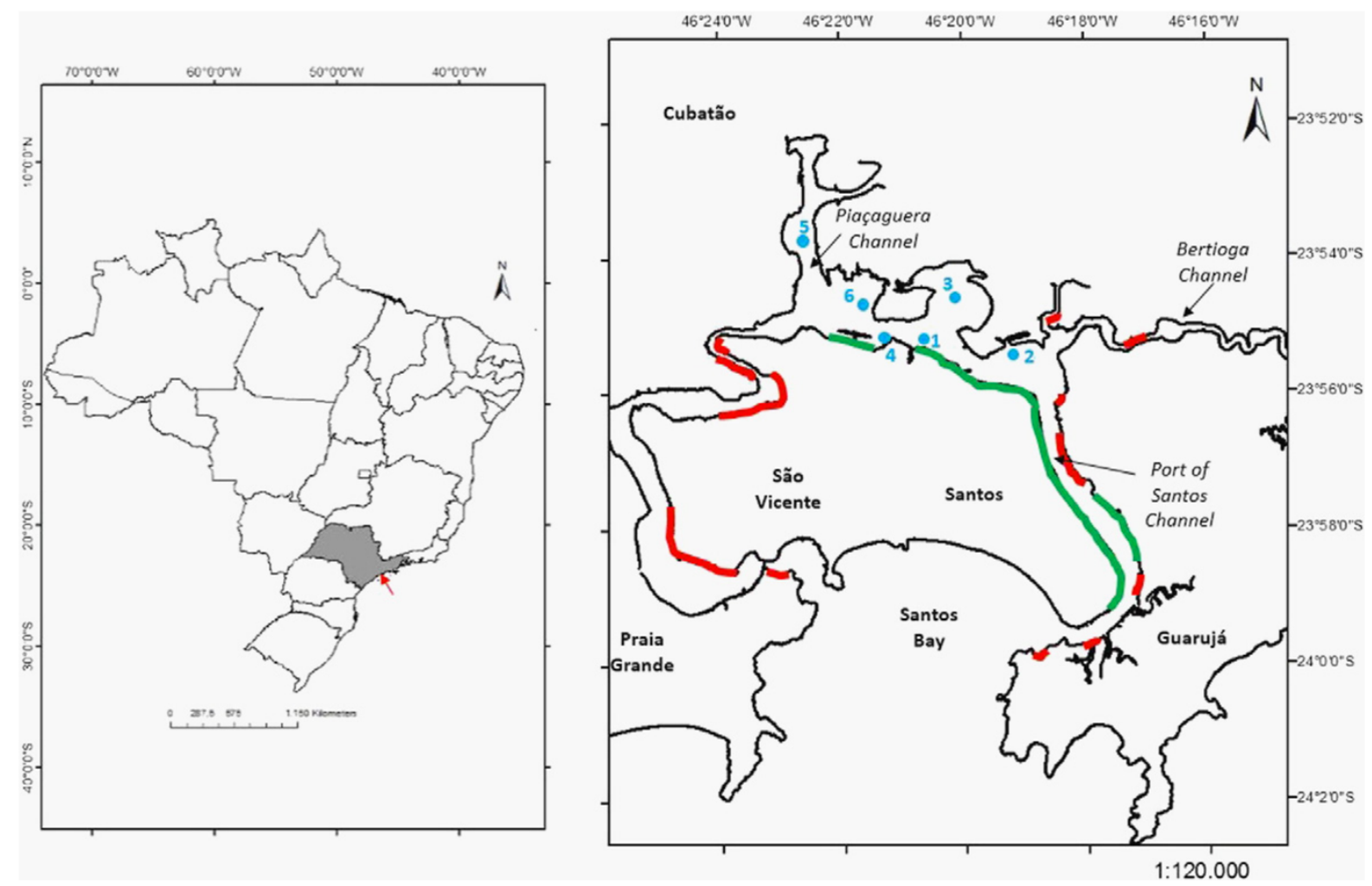

Fig. 1. Study area location: estuarine system of Santos-São Vicente. In red are the locations and distribution of irregular dwellings and stilt houses; In green, the location of berths of the Port of Santos; numbers 1-6 represent the location of the sampling stations. 


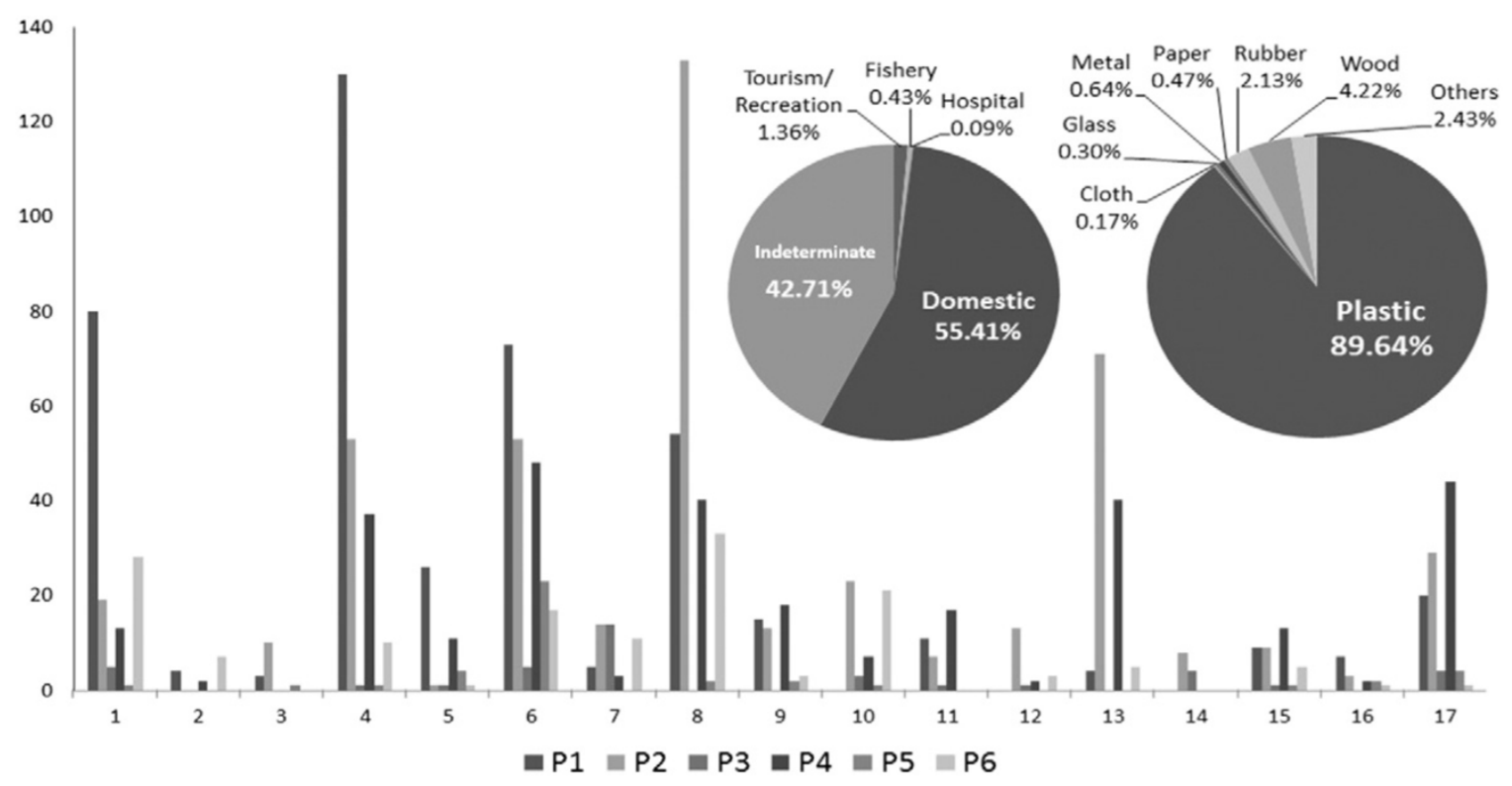

Fig. 2. Floating litter occurrence, materials and sources. The $Y$-axis represents the absolute quantity of litter per station in each campaign, the $X$-axis represents each sampling campaign $(n=17), P 1$ through P6 represent each sampling station indicated in Fig. 1. Left pie-chart illustrates representativeness of the inferred sources of the floating litter. Right pie-chart illustrates representativeness of types of material. 


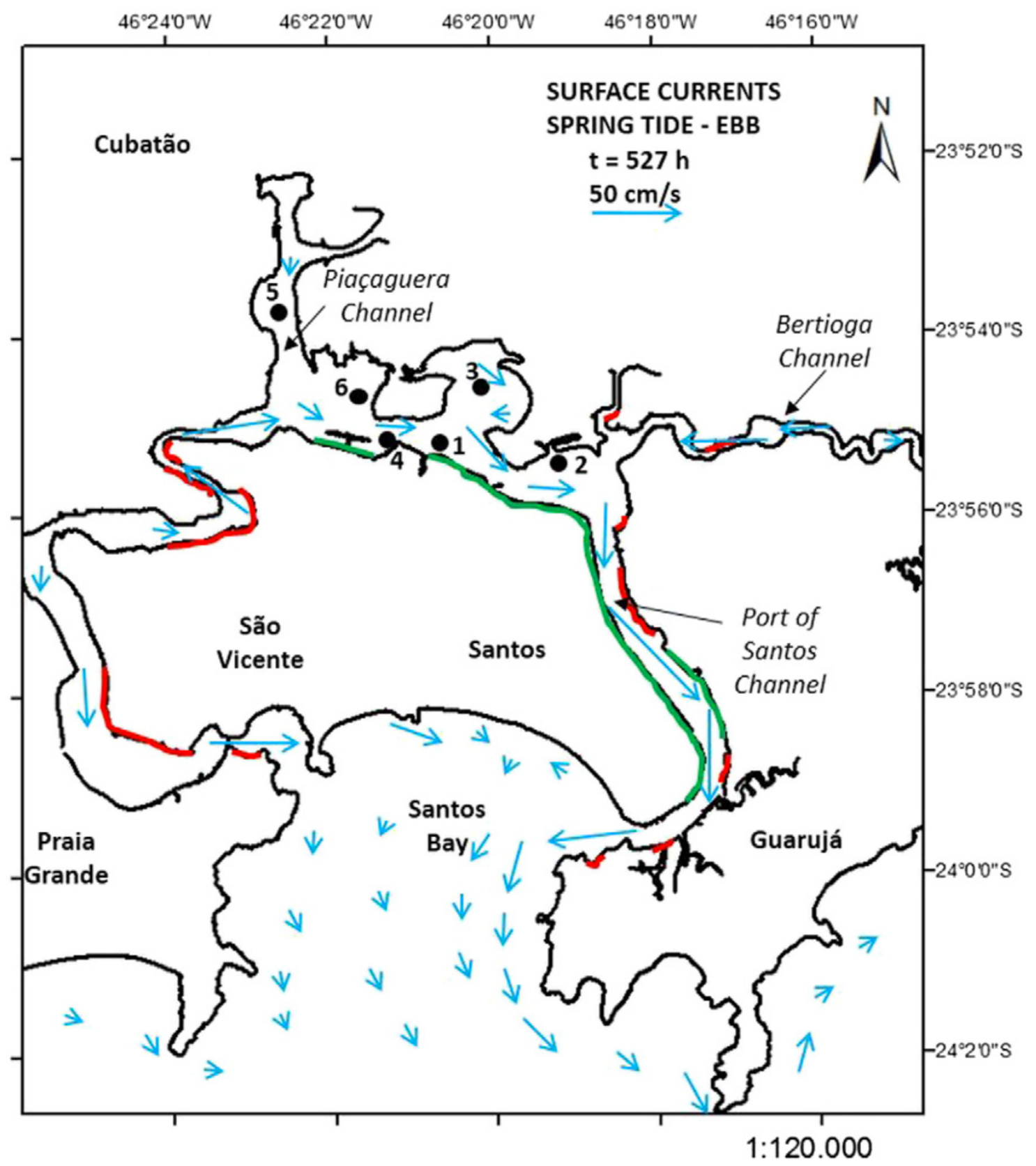

Fig. 3. Surface currents in the estuarine system of Santos-São Vicente. Red lines represent the approximate location of irregular dwellings/stilt houses in the margins of the main channels; Green lines mark the location of berths of the Port of Santos; numbers 1-6 represent the location of the sampling stations; Blue arrows indicate the direction and intensity of surface currents. 


\section{Tables}

\section{Table 1}

Occurrence of floating litter according to different tide regimes.

\begin{tabular}{lll}
\hline & Ebb (items/campaign) & Flood (items/campaign) \\
\hline Neap & 120.33 & 62.5 \\
Spring & 78.11 & 59.89 \\
\hline
\end{tabular}

This is the "accepted manuscript" originally published in Marine Pollution Bulletin at https://dx.doi.org/10.1016/j.marpolbul.2016.05.080. This version is licensed under a CC-BY-NC-ND license. 